\title{
Career Success Model: A Case Study of Information Technology Graduates
}

\author{
http://dx.doi.org/10.28932/jutisi.v7i3.4082
}

Riwayat Artikel

Received: 14 Oktober 2021 | Final Revision: 21 November 2021 | Accepted: 22 November 2021

\author{
Julianti Kasih ${ }^{\bowtie}$ \#1, Doro Edi ${ }^{* 2}$, Radiant Victor Imbar ${ }^{\# 3}$ \\ \#Program Studi Teknik Informatika, Universitas Kristen Maranatha \\ Jl. Surya Sumantri No. 65 Bandung \\ ${ }^{1}$ julianti.kasihemaranatha.ac.id \\ *Program Studi Sistem Informasi, Universitas Kristen Maranatha \\ Jl. Surya Sumantri No. 65 Bandung \\ ${ }^{2}$ doro.ediemaranatha.ac.id \\ ${ }^{3}$ radiant.vi@maranatha.ac.id
}

\begin{abstract}
Success in a career is everyone's dream, and it is not an exception for Information Technology graduates who are engaged in information technology-related jobs. Several studies have documented the role of the following two (2) constructs, namely Career Competence (CC) and Lecturer Competence (LC), in Career Success (CS). The authors believe that University Commitment (UC) must be included in this list. This research aims at developing a model that explains and measures the relationship amongst those four (4) constructs. The model that will be developed is based on the Structural Equations Modelling Technique. Respondents participating in this research are IT graduates working in IT-related jobs who have graduated from three (3) private universities in Bandung (Indonesia), namely, Maranatha Christian University (UKM), Parahyangan Catholic University (UNPAR), and Harapan Bangsa Institute of Technology (ITHB)) with graduating years ranging from 2006 to 2018. The collected data will be processed using IBM SPSS AMOS. This research proves that firstly, LC influences both UC and CC, secondly, UC influences CC, and lastly, CC affects CS. Further hope this model can be developed for other universities in Indonesia to increase Lecture Competency and University Commitments by the strategic plans of each university.
\end{abstract}

Keywords - Career Success, Commitment of Higher Education Lecturer Competency, Career Competence, Information Technology Graduates.

\section{INTRODUCTION}

Career success has been defined as the sum of externally or internally perceived positive job-related and psychological outcomes derived from one's work experiences [1, p.2]. Moreover, In the post-modern working life, this definition has been changed by individual perception and expectation of the successful career [2, p.365]. Therefore, some qualitative studies have been conducted to define what factors influence their success in a career. Previous studies said a significant relationship between career success and career competencies that can develop through education and training. [3, p. 65] Career competencies affect career success by one's ability to apply one's knowledge, skills, teamwork, leadership, and enthusiasm to work.

For graduates to have career success, young people will look for educational programs that prepare them for successful careers [4, p. 401]. Moreover, the Commitment of Higher Education to develop Education and Lecturer Competencies to get good graduates needs to be maximized. For this reason, this study seeks to measure the influence of Higher Education Commitments and Lecturer Competencies to improve the student's Competencies, so they succeed in pursuing their careers.

We cannot find the criteria in a research journal with the keyword "Career Success \& Information Technology \& Private University \& in Bandung." Therefore, the researchers want to focus on data processing Graduates from the Information Technology Department at three Education institutions in Bandung, Maranatha Christian University, Parahyangan Catholic University, Harapan Bangsa Institute of Technology to research subjects. I will see responses from graduates through a stretch of 20 years after graduation, while the researchers are members of the Information Technology Department. 
Choosing these institutions comes from the perspective that each institution has an Informatics and Information Systems program and has similar profile graduates who will compete to find work in the Bandung and West Java regions.

We will distribute the questionnaire, process it with the SPSS-IBM SPSS AMOS program, and analyze, measure, and produce models and formulas as the reference material. The ultimate model of the Career Success of Information Technology graduates will be confirmed as an evaluation material for universities to get relevant solutions to enhance Career Competency.

\section{METHOD}

Early research on Career Success to Career Competence was directed by Lertwannawit in 2009 [3, p. 65] with Thai employees in tourism and hospitality sector respondents. The contribution of human capital such as computer and language skills, leadership and teamwork, and computer \& language skills will influence the subjectivity of one's success.

The previous study mentioned a relationship between Career Success and Career Competence which could be acquired through education and training [5, p.169]. Based on these assumptions, the authors investigate other education factors, including professional lecturers who develop their competencies to shape more effective methods. To present educational materials, "Effective education is represented by the figures of professional lecturers who are always developing their competence" [3, p. 67]. The following is the explanation of the construct of the model. There are four constructs in the career success model of information technology graduation, and they can be described as in the following:

1. Higher Education

Universities are institutions controlled by their commitment to education [6, p. 3] DIKTI Controlling the Universities' quality by using The National Accreditation Board of Higher Education Assessment. More specifically, there are seven standards for assessing the accreditation of a university [6, p. 3]. Higher Education accreditation standards include standards regarding higher education commitment to institutional capacity; commitment to the effectiveness of educational programs, which are involved in seven accreditation standards, as in the following: Standards 1. Vision, mission, goals and objectives, and achievement strategies, measures 2. Security, leadership, management systems, and quality assurance, Standard 3. Students and graduates, standard 4. Human resources standard 5. Curriculum, learning, and academic atmosphere standard 6. Financing, facilities and infrastructure, and information systems standard 7. Research, service/community service, and cooperation

2. Lecturer Competence

It is recognized that the lecturer is the spearhead in the delivery of knowledge to students; assumed that the Competence of lecturers leads to the development of career competencies which in turn affects career success. Two types of Competence are personal Competence and operational Competence. Individual Competence is knowledge about a particular subject, while functional Competence can teach something practically [7, p. 172]. Operational competencies as lecturers are cited in Law 14 of 2005" Concerning Teachers and Lecturers, specifying that lecturers must have a pedagogical skill, personal, social and professional competencies." With the following description [7, p. 6]

a. Professional competency, i.e., the breadth of academic insight and the depth of lecturers' knowledge of scientific material they use;

b. Pedagogic competencies, i.e., mastery of lecturers on various types of approaches, methods, classroom management, and training evaluations that are following the material characteristics and development of students;

c. Personality competency, that is, the ability of the lecturer to present himself as an example and demonstrate enthusiasm and passion for his profession;

d. Social Competence is the ability of lecturers to respect pluralism, be active in various social activities, and perform in teamwork. For personal Competence, three manifest variables as specified in the List of Competency Indicators: Knowing an empathetic attitude to students, gaining enthusiasm in explaining, and passing on ideas sound [8, p. 8]. Overall there are seven illustrates in the construct of Lecturer Competence in this model.

3. Career Competence

"Career competencies can be described as self-management of his or her work and having experiences to achieve desired career progress." Several variables are given to illustrate career competencies, i.e., "Leadership, Ability to work, Spirit in Work, Computer Knowledge and Expertise "[3, p. 67]. The four manifest variables will be applied as a measurement tool to indicate the unobserved Career Competency variables.

4. Career Success

Career success is declared to be an individual achievement collected from the accumulation of his experience at work. Also, career success, defined as individuals' feelings of accomplishment and satisfaction with their careers. There is a link between objective success and subjective appraisals in that individuals express their success based, 
in part, on their objective accomplishments." [9, p. 487] Understanding career success can be split into two parts, i.e., describing objectively and subjective [3, p. 69], described in Table 1.

TABLE 1.

CAREER SUCCESS SCALE ITEMS

\begin{tabular}{l}
\hline Career Success Scale Items \\
\hline Objective Career Success \\
\hline Jobs responsibility (not challenge - challenge) \\
\hline Current position (do not meet the requirement -meet requirement) \\
\hline Compensation compared with the expense (not enough - enough) \\
\hline Salary and compensation compared with others in the same career (less- more) \\
\hline Subjective Career Success \\
\hline Happiness (no happiness - high happiness) \\
\hline Satisfaction in working life (dissatisfy - satisfy) \\
\hline Social acceptance (not acceptable- acceptable) \\
\hline Career actualization (no career actualization- high career actualization) \\
\hline
\end{tabular}

The Structural Equation Model is a statistical interpretation tool that combines factor analysis and regression [10, p. 1]. Structural Equation Model is a method for making models that can explain the relationship between variables. Many variables are: classified as latent variables (constructs) such as commitment. Investigators cannot measure responsibility because it is complex scientists must measure with a collection of deeper details called manifest variables. Without several indicators, latent variables cannot be calculated.

\section{RESULT AND DISCUSSION}

\section{A. Collecting Data}

The statistics applied in this research are collected from the 215 alumni of three universities, the passing year after 2000. The Development Career Success Model of Information Technology Graduation is designed as looked at in Figure 1. Measurement model testing is a test of each construct in the Development Model of Career Success.

The results show the significance of each X1 to X25 manifest variable on each construct of the model. Then, the measurement full structure model is conducted. There are two primary tests, essentially testing the model's accuracy and then examining the causality of relationships between constructs to prove the Hypothesis. 


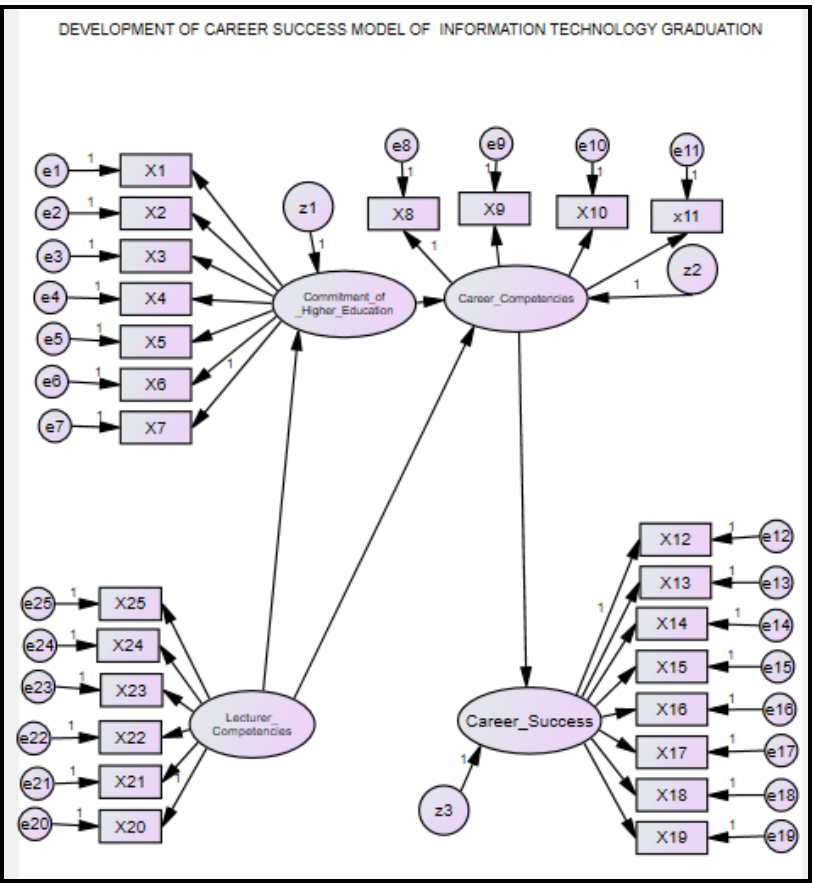

Figure 1. Development of a Career Measurement Tool for Information Technology Graduates

Any variable predicted by another variable or set of variables must have a residual value. Each residual will have a name, beginning with e1. It means $\mathrm{e} 1$ is residual for $\mathrm{x} 1$, e 2 is residual for $\mathrm{x} 2$, etc. The residual for a constructed variable is named $\mathrm{z}$. In this case, it is $\mathrm{z} 1$ up to $\mathrm{z} 3$. [13, p.32]

Many indices that show the accuracy of the models we take are varied, specifically CMIN, Goodness of Fit Index (GFI), RMSEA (Root Mean Square Error of Approximation), and PCFI (Parsimony adjustment to the CFI) [11, p. 63]

The following are the results: of testing the accuracy of the model:

- The limit of CMIN / DF $\leq 2.00-->$ in the Career Success Model

- Calculation: CMIN/DF $2.3 \alpha$ excess 0.3 This means that this model is less fit

- Limit of GFI between 0 (not fit) to 1 (very fit)

- The results of GFI 0.801 indicate that the model is within the applicable or precise limits to the data.

- RMSEA standard value $\leq 0.08$, RMSEA 0.079 results, so the model still displays the accuracy of the model

- PNFI has a limit of $\geq 0.5$; In this situation, the result of PNFI 0.0685 shows that the model is even within the proper sets. The result is that the model has acceptable certainty.

\section{B. Testing for Full Structure Model}

Testing here is also indicated as a causality test to check the assumption generated from the model. From the results obtained below, a hypothesis analysis will be generated. The present is as follows:

- Result (Default model)

- Maximum was Achieved

- $\quad$ Chi-Square $=634,549$

- Degrees of Freedom $=271$

- Probability level =,00

The model that can be analyzed is over-identified (DF positive) [12, p. 130]. The positive value of Degrees of Freedom results on the processing data model above means the further analysis of the model of Career Success is likely. The following is Figure 2 Output Estimation as the result of the SPSS AMOS calculation. 


\begin{tabular}{|c|c|c|c|c|c|c|c|}
\hline \multicolumn{6}{|c|}{ Unstandartdized } & \multicolumn{2}{|c|}{ Standartdized } \\
\hline \multicolumn{8}{|c|}{ Regression Weights: (Group number 1 - Default model) } \\
\hline & & & Estimate & S.E. & C.R. & P & Estimate \\
\hline Komitmen_Perguruan_Tinggi & $<-$ & Kompetensi_Dosen & .897 & .147 & 6.113 & $* * *$ & .696 \\
\hline Kompetensi_Karier & $<--$ & Komitmen_Perguruan_Tinggi & 687 & .118 & 5.817 & $* * *$ & .664 \\
\hline Kompetensi_Karier & $<-$. & Kompetensi_Dosen & .391 & 118 & 3.316 & $\cdots$ & .293 \\
\hline Kesuksesan_Karier & $<-$. & Kompetensi_Karier & .448 & .089 & 5.006 & $* * *$ & 677 \\
\hline xs & $<-.-$ & Kompetensi_Karier & 1.000 & & & & .713 \\
\hline $\mathrm{x} 9$ & $<--$ & Kompetensi_Karier & .993 & .105 & 9.476 & $* * *$ & .700 \\
\hline $\mathrm{x} 10$ & $<-$. & Kompetensi_Karier & .821 & .093 & 8.825 & $* * *$ & .651 \\
\hline $\mathrm{X} 12$ & $<-$. & Kesuksesan_Karier & 1.000 & & & & .415 \\
\hline $\mathrm{x} 13$ & $<--$ & Kesuksesan_Karier & .917 & .231 & 3.961 & $* * *$ & .361 \\
\hline $\mathrm{X} 14$ & $<-$. & Kesuksesan_Karier & 1.258 & .246 & 5.119 & $\ldots$ & .576 \\
\hline $\mathrm{x} 7$ & $<-$ & Komitmen_Perguruan_Tinggi & 1.000 & & & & .584 \\
\hline $\mathrm{x} 6$ & $<-$ & Komitmen_Perguruan_Tinggi & 1.046 & .152 & 6.902 & $* * *$ & .581 \\
\hline$\times 5$ & $<-\cdots$ & Komitmen_Perguruan_Tinggi & .721 & .126 & 5.721 & $\ldots$ & .458 \\
\hline $\mathrm{x} 4$ & $<-$ & Komitmen_Perguruan_Tinggi & 1.022 & .127 & 8.060 & $* * *$ & .726 \\
\hline $\mathrm{x} 3$ & $<-$ & Komitmen_Perguruan_Tinggi & .934 & .121 & 7.712 & $\ldots$ & .679 \\
\hline $\mathrm{x} 2$ & $<-\cdots$ & Komitmen_Perguruan_Tinggi & 1.023 & .128 & 8.001 & $* * *$ & .718 \\
\hline $\mathrm{x} 1$ & $<-$ & Komitmen_Perguruan_Tinggi & 1.099 & .135 & 8.130 & $* * *$ & .736 \\
\hline $\mathrm{X} 15$ & $<\ldots$ & Kesuksesan_Karier & 1.373 & .269 & 5.102 & $\cdots$ & .572 \\
\hline $\mathrm{X} 16$ & $<-\infty$ & Kesuksesan_Karier & 1.480 & .271 & 5.466 & $* * *$ & .683 \\
\hline $\mathrm{X} 17$ & $<-$ & Kesuksesan_Karier & 1.547 & .274 & 5.642 & $\cdots$ & .755 \\
\hline $\mathrm{x} 18$ & $<-$ & Kesuksesan_Karier & 1.608 & .304 & 5.291 & $* * *$ & .625 \\
\hline $\mathrm{x} 19$ & $<-$ & Kesuksesan_Karier & 1.445 & .265 & 5.457 & $* * *$ & .679 \\
\hline$\times 11$ & $<-$. & Kompetensi_Karier & 1.034 & 101 & 10.265 & $\ldots$ & .762 \\
\hline $\mathrm{X} 20$ & $<-\cdots$ & Kompetensi_Dosen & 1.000 & & & & .599 \\
\hline $\mathrm{X} 21$ & $<-$ & Kompetensi_Dosen & 1.211 & .150 & 8.075 & $* * *$ & .695 \\
\hline $\mathrm{X} 22$ & $<-$ & Kompetensi_Dosen & 1.401 & .163 & 8.569 & $* * *$ & .759 \\
\hline $\mathrm{X} 23$ & $<--$ & Kompetensi_Dosen & 1.321 & 169 & 7.813 & $* * *$ & .664 \\
\hline$\times 24$ & $<\ldots$ & Kompetensi_Dosen & 1.505 & 169 & 8.929 & $\ldots$ & .810 \\
\hline $\mathrm{X} 25$ & $<-\cdots$ & Kompetensi_Dosen & 1.273 & 146 & 8.698 & $* * *$ & .776 \\
\hline
\end{tabular}

Figure2. Output Estimation

Applied to the model above, we will have the fulfillment of four Hypotheses.

- Hypothesis 1. There is a contribution of lecturers' competencies that affect the commitment of higher education. \{Unstandardized estimates: 0.897 and standardized: 0.696; P <0.05 (***)\}

- Hypothesis 2. There is the Influence of Competency of Lecturers with Graduates Career Competencies \{Unstandardized Estimates: 0.391 and Standardized: 0.293; P $<0.05(* * *)\}$

- Hypothesis 3. Effect of Construct Commitment of Higher Education with Proven Career Competencies \{Unstandardized Estimates: 0.687 and Standardized: 0.664; $\mathrm{P}<0.05(* * *)\}$

- Hypothesis 4. Positive relations between constructs of Career Competence and Career Success are created \{Unstandardized estimates: 0.448 and standardized: $0.677 ; \mathrm{P}<0.05(* * *)\}$

The Full Structure Model test results show that the significance of the manifest and construct is found.

The above model presents not to instruct driving through a trimming process because the relationship between constructs and manifest is found valid. Based on that result, therefore, the model is checked for its validity to be analyzed further.

\section{CONCLUSION}

\section{A. Structural Equation Analysis Result}

Career Success Variable is influenced by three variables: Career Competency, Higher Education Commitment, and Lecturer Competency. When expressed in a regression equation, the construct is as follows: [12, p. 215$].$
$\mathrm{KPM}=\beta 1 \mathrm{KD}+\mathrm{z} 1$
$\mathrm{KompK}=\beta 1 \mathrm{KD}+\beta 2 \mathrm{KPM}+\mathrm{z} 2$
$\mathrm{KsskK}=\beta 1 \mathrm{KompK}+\mathrm{z} 3$

Described in the construct of an equation are as follows:

$\mathrm{KPM}=0.90 \mathrm{KD}+\mathrm{z} 1$

$\mathrm{KompK}=0.39 \mathrm{KD}+0.69 \mathrm{KPM}+\mathrm{z} 2$

$\mathrm{KsskK}=0.45 \mathrm{KK}+\mathrm{z} 3$

$\mathrm{KPM}=$ Higher Education Commitment

$\mathrm{KD}=$ Lecturer Competence

KompK = Career Competence

KsskK = Career Competency

$\beta 12=$ Regression Coefficient

z1,2,3 = Disturbance Term 
The Career Success Measuring Instrument development in this paper is based on four variables, namely Career Competence, University Commitment, and Lecturer Competence and Career Success, which the model illustrates in Figure 1. Model of Career Success Measuring Instrument Graduates of Information Technology. The explanation of the Constructions and Manifests are listed in Table 1, i.e., the Table of Constructions and Manifest Model of the Career Success Measure of Information Technology Graduates. This development is based on previous research and some literature listed in the INTRODUCTION.

After testing the Information Technology Graduates using the "Career Success Model," the results of the Goodness of Fit and Degrees of Freedom Tests, The Measurement Model, and Full Structural Model Tests demonstrate that the Information Technology Graduates' Career Success Measurement Model is appropriate. It doesn't appear to require a trimming process. These results support the author's Hypothesis that the three variables are Career Competence, Higher Education Commitment, and Lecturer Competence, which affect the Career Success of Information Technology graduates. Based on the ends of these tests, it can be determined that the final model of the Career Success of Technology graduates did not shift from the original measures, as shown in Figure 1.

Full Structure Model Analysis Results show that variables that directly influence Career Success Information Technology Graduates have the most significant value (.677) compared to other variables like Career Competency variables. It indicates that courses delivered to Information Technology students must include certifications that reinforce the competencies of graduates. The second variable that indirectly influences the Career Success of Information Technology Graduates (.511) is the Lecturer Competency variable.

Based on these results, an increase in the Competence of lecturers is thought to be necessary to ensure graduates successfully compete in a world moving towards an Industrial Era 4.0.

\section{B. Questionnaire Analysis Results among the Three Colleges}

Manifest X11, which describes a questionnaire with the phrase competence of lecturers in Higher Education, is apparent from the enthusiasm of one's work. The highest response from respondents of the three tertiary institutions is from UKM. The acquisition of the average value of respondents from UNPAR amounted to 4,502; UKM: 4,659; ITHB: 4,563. We require knowing that manifest X11 has a construct of Lecturer Competence. From this result, all respondents firmly state that the morale of the lecturer will influence the Competence of the lecturer concerned, and that is the variable that most influences the Career Success of Information Technology Graduates.

\section{(i) Parahyangan University}

The questionnaire answer with the lowest value in manifest X7 $(3,640)$, which is the commitment of higher education is manifested in the implementation of research and service. It shows that respondents from Parahyangan University have neutral opinions about indicating the performance of research and community service as part of the University Commitment.

\section{(ii) Maranatha Christian University}

Manifestation Career success is created by someone who has a Promotion (X12) recognized as something that can or cannot determine one's Career Success. The results show that manifest with the lowest score from Maranatha Christian University respondents

\section{(iii) Harapan Bangsa Institute of Technology}

Institute of Technology's respondents consider that Social Acceptance can or can not be used to measure one's Career Success. The displayed in the answer X18 manifest of 3,713, which is the lowest average answer value linked to other manifests

If we summarize the results of all respondents as follows:

a. The respondents strongly agreed that the morale of the lecturers influences the Competence of the lecturers concerned and Lecturer's Competence is the variable that exerts the most influence on one's Career Success.

b. The Promotion and Social Acceptance as a manifestation of Career Success and implementation of Service and Research as a manifestation of Higher Education Commitment: considered able/unable to determine "one's career success. "It is required that the results of this study can be worked as input for the relevant universities in this study that the perceptions of graduates towards the Competence of lecturers as manifested in the work spirit will enormously influence career success in the future. Furthermore, it is desired that increasing Lecturer Competence will maintain to be undertaken to raise the quality of graduates to pursue careers successfully.

Based on the results of this study, the suggestion was remark such as: 
Higher Institutions need to improve the quality of being prominent universities. One way is to increase the achievement of the Accreditation score based on College Standards based on the Assessment of the National Accreditation Board of Higher Education. Technology is developing rapidly; therefore, Lecturers of the Faculty of Technology need to improve their Competence to produce successful alumni that have the ability according to the needs of the community

The Students need to gain experience from successful alumni, improve their abilities during their study and reach career success of Information Technology alumni.

For further research, in the area of Geography of the universities from the respondence, can be developed. For example, Information Technology Graduates of Private Colleges vs. Information Technology Graduates of public Colleges in Java, to see more in-depth comparisons to enhance the quality and career success of Information Technology Graduates.

\section{ACKNOWLEDGMENT}

Our highest appreciation to our institution, Maranatha Christian University. Especially in supporting and funding this research.

\section{REFERENCES}

[1] Arthur, M. B., Khapova, S. N., \& Wilderom, C. P. M. Career success in a boundaryless world. Journal of Organizational Behavior, 26(2), 177-202. in De Aloveira,M.C.,Silva, L.L.M., Trivera, M.C., Postigo, F.L.J

"Career Success According to New Graduates: Implications for Counseling and Management." School and Educational Psychology Vol. 29, p.2, 2019 https://www.scielo.br/pdf/paideia/v29/1982-4327-paideia-29-e2913.pdf

[2] Dries, N The meaning of career success: Avoiding reification through a closer inspection of historical, cultural, and ideological contexts. Career Development International, 16(4), 364-384, $2011 \mathrm{http}: / / \mathrm{dx}$.doi.org/10.1108/13620431111158788

[3] Lertwannawit. A., Serirat.S., \& Pholpantin.S. "Career Competencies and Career Success of Thai Employees In Tourism," International Business \& Economics Research Journal, vol. 8, no. 11, p. 65, November 2009. https://clutejournals.com/index.php/IBER/article/view/3186/3234

[4] Ravindran.S and M. Kalpana, "Students' Expectation, Perception and Satisfaction towards the Management

Educational Institution," in 2nd Annual International Conference on Accounting and Finance, Singapore, 401-410, 2012. https://doi.org/10.1016/S2212-5671(12)00102-5

[5] Kuijpers, Marinka A.C.T, Schyns., Birgit, S. Jaap ” Career Competencies for Career Success. "The career Development Quarterly vol 55, p.169, December 2006 https://doi.org/10.1002/j.2161-0045.2006.tb00011.x

[6] T. P. N. A. I. P. Tinggi, "Akreditasi Institusi Perguruan Tinggi," Buku II Standar dan Prosedur, p. 5, Febuari 2015. https://spma.gunadarma.ac.id/wp-content/uploads/2010/06/Buku-02-Standar-dan-Prosedur-AIPT.pdf

[7] P. R. Indonesia, UNDANG-UNDANG REPUBLIK INDONESIA No 14 Tahun 2005 tentang Guru dan Dosen, Jakarta, 2005 http://luk.staff.ugm.ac.id/atur/UU14-2005GuruDosen.pdf

[8] W. Widhiarso, Validasi Model Kompetensi Dosen Dalam Pembelajaran Berbasis Student, Yogyakarta: Seminar Hasil Penelitian UGM, 2010. https://papers.ssrn.com/sol3/papers.cfm?abstract_id=1848843

[9] J. A. Timothy, Cable D.M, Boudreau J.W., Bretz R.D "An Empirical Investigation of the Predictors of Executive Career Success," Personal Psychology 48,485-519, 1995. https://doi.org/10.1111/j.1744-6570.1995.tb01767.x

[10] S. Santoso, AMOS 22 Untuk Structural Equation Modelling, Jakarta: Elex Media Komputindo, 2015.

[11] A. Ferdinand, Structural Equation Model Dalam Penelitian Manajemen, Semarang: Badan Penerbitan Universitas Diponegoro- Indoprint Semarang, 2006

[12] I. Ghozali, Konsep dan Aplikasi dengan program Amos 16.0, Semarang: Badan Penerbit Universitas Diponegoro, 2008.

[13] Division of Statistics + Scientific Computation, Structural Equation Modeling Using AMOS An Introduction, The University of Texas at Austin, 2012 